\title{
Corporate Governance Changes Following Earnings Restatements: A Research Tool
}

Aliza Rotenstein, Yeshiva University, USA

\begin{abstract}
This study develops a research model to investigate whether firms that restate previously released financial reports implement subsequent changes in internal governance in an effort to correct underlying problems that contributed to the need for restatement in the first place. In doing so, various likely responses to financial reporting problems, including board, audit, and management changes, are indexed into a single measure to assess the joint strength of multiple corporate governance attributes within a firm. The paper demonstrates how a comparison of the Index before and after a restatement may be used to relate the nature and magnitude of a restatement with the likelihood of corporate governance changes in the aftermath of restatement. Further, the paper classifies sample restatements more finely on the basis of presence of fraud, prompter, magnitude, severity, and reason for the restatement. This more detailed classification recognizes that responses to restatements likely relate to particular characteristics of the restatement and the restatement firm. To illustrate the use of the Index in the research model, a sample hypothesis is examined, with findings showing a statistically significant association between restatements involving fraud and subsequent corporate governance changes.
\end{abstract}

Keywords: Restatements; Corporate Governance; Turnover; Fraud

\section{INTRODUCTION}

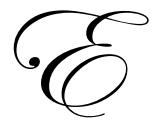

mpirical studies report that key corporate governance features, such as outside board members, separate CEO and Chairman of the Board positions, an independent audit committee, the use of a Big Four auditor, and a small board size, can be useful in reducing financial misreporting (e.g., Beasley, 1996; Dechow, Sloan, and Sweeney, 1996; Abbott, Parker, and Peters, 2004; Agrawal and Chadha, 2005; Farber, 2005; Baber, Kang, Liang, and Zhu, 2009). In these studies, both restatement and SEC-targeted fraud firms are associated with weaknesses in their internal corporate governance mechanisms. ${ }^{1}$ This relation between corporate governance quality and financial reporting credibility has been one driving force behind the euphoria surrounding corporate governance regulation in recent years. In particular, the Sarbanes-Oxley Act of 2002 enhanced regulatory standards for all U.S. public company boards and management by requiring the certification of financial reports by top managers and by establishing harsh criminal penalties for altering or falsifying records. ${ }^{2}$

The heightened interest in the governance of U.S. firms has resulted in part from a restatement trend in recent years (Abbott et al., 2004). According to the U.S. Government Accountability Office (GAO, hereafter), the number of financial statement restatements steadily rose from 92 in 1997 to 370 in $2004 .{ }^{3,4}$ In addition, consequences to restatement firms have been severe, typically resulting in large losses in market value following announcements of restatements, which are sometimes accompanied by legal actions by investors and/or the

\footnotetext{
${ }^{1}$ Baber et al. (2009) find that it is weak external governance mechanisms rather than internal governance mechanisms that relate to the occurrence of restatements.

${ }^{2}$ Sections 302 and 802 , respectively.

${ }^{3}$ There was a slight drop in number of firms restating between 2002 and 2003 (GAO, 2006).

${ }^{4}$ In a follow-up study by the GAO, the number of restatements showed little sign of abating, climbing to 523 in the January 2005 through September 2005 period (GAO, 2006).
} 
Securities and Exchange Commission (SEC, hereafter) (e.g., GAO, 2002; Wu, 2002; Palmrose, Richardson, and Scholz, 2004; Palmrose and Scholz, 2004). ${ }^{5}$ Other studies document increases in the cost of equity capital following restatements, making it more costly for these firms to acquire future financing (Hribar and Jenkins, 2004; Anderson and Yohn, 2002) and decreases in the earnings response coefficient, reducing the information content of earnings (Wu, 2002; Wilson, 2008). In sum, financial statement restatements appear to be important and significant economic events for exchange-traded firms in the United States.

The purpose of this paper is to develop a method to investigate whether firms that restate previously released financial reports implement subsequent changes in internal governance in an effort to correct underlying problems that contributed to the need for restatement in the first place. In doing so, various likely responses to financial reporting problems, including board, audit, and management changes, are indexed into a single measure. Prior studies have examined selective aspects of changes to corporate governance in the period following a restatement, including the turnover of senior management and board members (e.g., Desai, Hogan, and Wilkins, 2006; Srinivasan, 2005) and the reduction in both bonus payments (Collins, Reitenga, and Sanchez-Cuevas, 2008) and the proportion of option-based compensation (Cheng and Farber, 2008) for CEOs. This study goes beyond prior literature on the topic by further examining the link between restatements and internal corporate governance changes. In doing so, a broad measure of corporate governance that encapsulates board, audit, and management elements is created in an effort to assess the joint strength of multiple corporate governance attributes within a firm.

While it would appear reasonable to think that all firms would prefer to correct problems that prompted restatements, a reform in corporate governance does not necessarily follow restatements. It is possible that entrenched and/or overconfident managers may not fully recognize the need to implement nor the value of implementing governance changes and thus choose not to undertake improvements. Further, in technical restatements, such as those that arise in response to guidance by the SEC or the Financial Accounting Standards Board (FASB, hereafter), governance changes are, perhaps, less necessary and therefore less likely. Prior studies do not control for all the variation in the characteristics of restatements. For example, Desai et al. (2006) do not differentiate restatements by their relative effects on firms' financial statements or by the stated reason for the restatement. It is likely, though, that responses by firms following restatements might vary according to the severity and reason for the restatement.

This paper makes two chief contributions to the literature. First, the study classifies GAO restatements more finely on the basis of presence of fraud, prompter, magnitude, severity, and reason for the restatement. This classification recognizes that responses to restatements likely relate to particular characteristics of the restatement as well as to individual firm characteristics that were present in prompting the need for restatement. Second, the paper develops a research model designed to relate the nature of a restatement with the likelihood of corporate governance changes and to identify those features that are most strongly associated with governance changes.

The following section outlines the theory and research methodology. Section 3 develops a regression model, Section 4 describes the sample selection process and the sample firms, and Section 5 explains the method used to construct the governance index and the dependent variable. Empirical results for a sample hypothesis are reported in Section 6, and Section 7 concludes.

\section{THEORY AND RESEARCH METHODOLOGY}

Much of the restatement literature parallels a more developed body of literature concerning financial statement frauds. However, while fraudulent activity could result in the need for restatement, restatements do not necessarily involve fraud and thus represent a broader group of firms. Moreover, firm and governance characteristics in the two settings might be quite different, resulting in different causes for as well as responses to the respective financial reporting problems. Specifically, financial statement fraud often stems from poor managerial oversight, spiraling from weak internal control systems. Because internal controls are ineffective, management turnover and

\footnotetext{
${ }^{5}$ Palmrose et al. (2004) report a significant average abnormal return of $-9.2 \%$ over a 2-day announcement window. Similarly, the GAO Report finds that stock prices of restating companies over the 1997 to 2001 period fell $9.5 \%$ on average, over a 3-day announcement window.
} 
other changes in governance are likely to follow fraud detection as a means to curb fraudulent behavior and strengthen the internal control system. ${ }^{6}$

In contrast to this, many restatements do not arise due to poor managerial oversight and outright fraudulent activities. Rather, it is often overconfident and, possibly, entrenched managers who engage in overly aggressive accounting methods that leads to the need for restatement. ${ }^{7}$ For example, managers have discretion in obtaining estimates relating to bad debt allowances, accruals, impairment of assets, recognition of gains and losses, and various timing issues, among others. Although they are not inherently fraudulent, consistently aggressive estimates may result in the need for restatements. It is possible that entrenched and/or overconfident managers may not fully recognize the value in implementing governance changes and thus choose not to undertake improvements. In overestimating their own abilities to benefit the company, they may actually make distorted decisions, resulting in the eventual need for restatements, with their associated losses in value to the firm.

In addition, restatements are sometimes merely technical adjustments for compliance or represent companies strengthening their internal controls. In particular, the certification of financial reports required by Section 302 and the internal controls provisions of Section 404 of the Sarbanes-Oxley Act of 2002 prompted restatements.

Consequently, while corporate governance changes are expected to follow restatements involving outright fraud, the reaction by firms to various non-fraudulent restatements and to other relatively technical restatements is unclear and remains an empirical issue. Considering the substantial costs associated with financial statement restatements, firms would likely seek to correct underlying problems that potentially contributed to the need for restatement. In this context, restatements might be expected to spur improvements in corporate governance arrangements. On the other hand, perhaps entrenched and/or overconfident managers do not initiate governance changes. Also, in other types of more technical restatements, governance changes are, perhaps, less necessary and therefore less likely. In general, the expectation is that governance responses to restatements likely relate to particular characteristics of the restatement as well as to individual firm characteristics that were present in prompting the need for restatement.

To assess a firm's overall corporate governance and any changes following a restatement, this paper develops a composite score computed using an array of governance features that may be adjusted in light of a financial statement restatement. This idea is similar to the "Governance Index" (G-Index), a composite measure of the strength in shareholder rights developed by Gompers, Ishii, and Metrick (2003). However, the index in this study differs from the G-Index, as the primary focus is on board strength as well as audit and management elements. A single score, comprising board, audit, and management features, is intended to give a more accurate portrayal of the joint strength of multiple governance attributes within a firm. A composite score is calculated in the year preceding a restatement announcement and then again two years following the restatement. The composite score provides a useful research tool, whereby any change in the composite score may be examined to find determinants of that change.

As with the G-Index, the composite score (Index, hereafter) may not accurately reflect the relative impact of different governance components. However, it has the advantage of being transparent, objective, and easily reproducible. Furthermore, as with the G-Index, the Index is a more efficient tool than pooling all the variables. Although certain corporate governance components might be expected to play a stronger role than others, substantial multicollinearity between the components would make it difficult to construct powerful tests. ${ }^{8}$ Consequently, the Index enhances the power of any tests that might be performed. ${ }^{9}$ Moreover, the Index provides a convenient method

\footnotetext{
${ }^{6}$ Findings by Feroz et al. (1991), Livingston (1997), and Farber (2005) support this expectation.

${ }^{7}$ This is based on the growing behavioral corporate finance literature that examines overtly confident CEOs who overestimate their ability to generate value within their company and thus systematically make distorted decisions about when, how, and how much to invest in new projects [see Malmendier and Tate (2005a, 2005b, 2008, 2009)].

${ }^{8}$ Gompers et al. (2003) find that there is lack of power in subindex regressions and that the relative importance of individual governance provisions cannot be measured exactly because of large standard errors that are partly due to multicollinearity between regressors.

${ }^{9}$ This refers to statistical tests where the Index is an independent variable (right-hand side).
} 
to compare changes to firms' corporate governance levels over time and to examine the determinants of those changes. ${ }^{10}$

The following sections describe the construction of the Index. Specifically, board, audit, and management characteristics are discussed in terms of findings documented in previous studies, and the Index is constructed in accordance with attributes shown in prior literature to be associated with "good" corporate governance.

\section{Board Features}

Numerous academic studies analyze the link between board composition and overall firm performance (Baysinger and Butler, 1985; Hermalin and Weisbach, 1991; Agrawal and Knoeber, 1996; Yermack, 1996; Klein, 1998; Bhagat and Black, 1999). Although results are mixed, there is no compelling evidence that firms with majority-independent boards perform better than firms without such boards (Bhagat and Black, 1999). However, greater board independence appears to improve key decisions made by management with respect to responding to takeovers, setting executive compensation, and approving new CEOs (e.g., Weisbach, 1988; Cotter, Shivdasani, and Zenner, 1997; Core, Holthausen, and Larcker, 1999).

Weisbach (1988) finds that more independent boards are more effective in their discipline of management, as indicated by a higher likelihood of CEO turnover following poor performance in firms with boards dominated by outsiders. Dahya, McConnell, and Travlos (2002) report similar results for a sample of U.K. firms. Moreover, recent public policy debate advocates independence of not only the full board, but also key oversight committees. ${ }^{11}$

Beyond independence, several other board characteristics have been discussed in prior literature. For instance, concerns about a lack of independent leadership are expressed in Jensen (1993), where he suggests that when the CEO also holds the position of Chairman of the Board, internal control systems seem to fail. Among the board's primary jobs is its responsibility to evaluate (and fire) the CEO. In boards where the CEO presides as chairman, it is possible that this job cannot be carried out effectively. Goyal and Park (2002) similarly find that CEO turnover is significantly less sensitive to firm performance in firms with combined titles than in firms with separate titles. $^{12}$

Yermack (1996) shows a positive association between a small board size and corporate valuation in large U.S. firms. In addition, other studies show negative effects when directors are involved in serving on other companies' boards (Core et al., 1999; Shivdasani and Yermack, 1999). Finally, interlocked directorships are found to have negative effects as well, especially in their association with higher CEO compensation and lower CEO turnover (Hallock, 1997; Core et al., 1999; Fich and White, 2003).

Given that some board attributes shown in prior literature are associated with "good" corporate governance, the Index increases by one if: (1) more than two-thirds of the board is comprised of independent directors; (2) all audit committee members are independent directors; (3) all compensation committee members are independent directors; (4) all nominating committee members are independent directors; (5) all corporate governance committee members are independent directors; (6) the titles of CEO and Chairman of the Board are not held by one individual; (7) the Chairman of the Board is an independent outside director; (8) the board size is less than the median of the distribution of all firms (adjusted for firm size and time); (9) the board interlock is less than the median of all firms (adjusted for firm size and time); or (10) the mean number of other boards served by a director is less than the median of the distribution of means of all firms (adjusted for firm size and time). These ten attributes are used to measure the strength of a board.

\footnotetext{
${ }^{10}$ In this case, changes to the Index would function as the dependent variable (left-hand side).

${ }^{11}$ The Sarabanes-Oxley Act of 2002 required that publicly-traded firms have audit committees composed solely of independent directors. Similarly, as of November 2003, companies listed on the NYSE are required to establish audit, nominating/corporate governance, and compensation committees composed entirely of independent directors, and companies with securities quoted on NASDAQ are required to have audit committees composed entirely of independent directors.

${ }^{12}$ In opposing this view, Brickley, Coles, and Jarrell (1997) suggest that the costs of separation may be larger than the benefits for most large firms.
} 


\section{Audit Features}

The consensus in prior studies that examine the value of audit firms is that Big Four audit firms provide better monitoring than other types of audit firms. For example, DeAngelo (1981) finds that larger audit firms provide a higher level of audit quality. Larger firms are more susceptible to negative consequences resulting from failure to perform satisfactorily and thus have less incentive to engage in opportunistic practices. Larger audit firms are also thought to face less litigation than other firms, because they provide higher quality audits (e.g., Palmrose, 1988). In view of this association, the Index increases by one if the firm employs a Big Six audit firm. ${ }^{13}$ Furthermore, the Index considers potential audit-firm changes (of any type) following a restatement. The Index increases by one in the post-restatement period (defined as two years following the restatement announcement) if there is a change in the external auditor since the pre-restatement period (defined as the year preceding the restatement announcement).

\section{Management Features}

The significant inverse relation between firm performance and the probability of top management turnover is a finding that has been widely documented throughout the accounting and finance literatures. ${ }^{14}$ Specifically, turnover is found to increase when firm performance deteriorates. This is most often the result of successful monitoring by boards of directors, other competing managers, large shareholders, and the threat created by the takeover market. Given a negative relation between corporate performance and top management turnover, it follows that the announcement of a restatement, with its associated decline in stock market performance, might result in a change in management. If internal monitoring mechanisms are effective, and if stock price performance reflects information on managers' efficiency, there should be a negative relation between the probability of a top management change and share price performance (Warner, Watts, and Wruck, 1998). Thus, top managers are expected to be held responsible for the occurrence of a restatement and its related stock market consequences.

To incorporate management changes into the study, the Index is adjusted according to the level of CEO turnover. If a restatement firm experiences a change in CEO between the pre-restatement and post-restatement periods, the Index increases by one in the post-restatement period.

\section{Calculation of Index-Change}

Index-Pre is calculated in the year preceding the restatement announcement, and Index-Post is calculated two years following the restatement. Index-Post / Index-Pre - 1 (Index-Change) is calculated as the percentage change between the two.

Index-Change demonstrates the extent of board, audit, and CEO changes implemented by restatement firms. By construction, the larger the score, the greater the extent of improvements.

\section{REGRESSION MODEL}

A regression model may be used to explore the relation between Index-Change and various restatement and firm characteristics thought to influence Index-Change. The expectation is that variation in Index-Change among restatement firms can be explained by restatement- and firm-specific characteristics. Broadly speaking, the decision to strengthen corporate governance following a restatement is a function of the type and severity of the restatement. Formally, this can be summarized by the equation below.

\footnotetext{
${ }^{13}$ The Big Six existed until Price Waterhouse merged with Coopers and Lybrand in 1998.

${ }^{14}$ See Benston (1985), Coughlan and Schmidt (1985), Weisbach (1988), Warner, Watts, and Wruck (1988), Gilson (1989), Martin and McConnell (1991), Murphy and Zimmerman (1993), Denis and Denis (1995), Kang and Shivdasani (1995), Franks and Mayer (1996), Mikkelson and Partch (1997), Huson, Parrino, and Starks (2001), Dahya, McConnell, and Travlos (2002), and Conyon and Florou (2002). For a review of the literature, see Furtado and Karan (1990).
} 
Index-Change $=\mathrm{F}$ (test variable, control variables)

For example, the expectation is that restatements that indicate lack of management integrity will motivate a decision to strengthen corporate governance and thus be positively related to Index-Change. As in Palmrose et al. (2004), restatements involving fraud are classified based on company disclosures of fraud (irregularities) or issuance of an SEC Accounting and Auditing Enforcement Release (AAER, hereafter). Since fraud represents intentional, non-GAAP financial reporting, it suggests lack of management integrity. Therefore, the following might be a reasonable hypothesis to test using Index-Change as part of the regression model.

Sample Hypothesis. There is a positive relation between restatements involving fraud and changes to strengthen firms' governance mechanisms in the period following the restatement.

In addition to the test variable, the following sections discuss several variables included in the model to control for firm characteristics that might affect changes in corporate governance.

\section{Pre-Restatement Governance}

The restatement firms in the sample have a maximum Index value between 3 and 13 (mean = 10.84; median = 11). The governance level in the pre-restatement period is calculated as the fraction represented by the Index divided by the maximum Index for that firm-year, less the median governance level in the same industry-year in the control sample of non-restatement firms. This measure is used to compare the pre-restatement governance level of each restatement firm to the remaining firms in the industry in that particular year. Presumably, the higher the prerestatement governance level, the greater the cost and effort needed for a restatement firm to enhance its governance mechanisms. ${ }^{15}$ Perhaps, in such a situation, a firm would be less inclined (or able) to expend the necessary resources. In addition, as a second control of pre-restatement governance levels, the pre-restatement period of each sample restatement is matched to the median governance level in the same industry-year in non-restatement firms. This variable is used to control for patterns in governance levels among the various industries.

\section{Firm Industry and Restatement Year}

Industry and restatement year variables are necessary to control for normal changes in corporate governance structure that vary by industry and by year. Previous studies have shown that restatements are more likely in certain industries, such as manufacturing and technology (Dechow, Sloan, and Sweeney, 1995; Burns and Kedia, 2006). In addition, the year of the restatement needs to be considered. For example, the Sarbanes-Oxley Act of 2002 imposed a number of regulations that mandated enhanced standards for all U.S. public company boards, management, and public accounting firms. Of particular consequence to the calculation of the Index, Section 301 of the Sarbanes-Oxley Act required all listed companies to have audit committees composed entirely of independent directors. In addition, the internal controls provisions of Section 404 likely prompted a number of restatements after 2002. As such, it is decidedly important to control for the effects of both the industry and the year of the restatement.

The median Index-Change over the prior three years is calculated for each industry-year in non-restatement firms, where an industry is defined by its 2-digit SIC code. The intuition for this calculation is as follows. IndexChange corresponds to the change in governance level between the pre-restatement and post-restatement periods. By construction, this represents a span of three years. Therefore, to control for "normal" changes in the Index over a three-year period, each sample restatement is matched to the median Index-Change for the corresponding industryyear in non-restatement firms. This control variable is referred to as Index-Change-Control.

\section{SAMPLE SELECTION AND SUMMARY STATISTICS}

The sample consists of 919 financial statement restatements issued by 845 public companies from January 1, 1997 through June 30, 2002, as identified by the 2002 GAO Report. These restatements were announced to

\footnotetext{
${ }^{15}$ Since governance changes come at a cost to the firm, the benefits need to outweigh the costs. The higher the pre-restatement governance level, the more costly improvements become, and the less likely it is that the benefits will outweigh the costs.
} 
correct previous material misstatements of financial results. The GAO database excludes announcements involving stock splits, changes in accounting principles, and other financial statement restatements that were not made to correct mistakes in the application of accounting standards.

The GAO Report supplies some useful data regarding each restatement announcement. For instance, restatements are categorized into one or more of nine major categories, such as revenue- and expense-related restatements. In addition, the prompter of each restatement (i.e., company, auditor, SEC) is identified. This paper further analyzes the restatements and partitions them on the basis of the magnitude of the restatement's effect on net income, the total number of financial periods restated, and the reason for the restatement, thus producing a more detailed classification of the restatement firms. These items are identified through a comprehensive search of restating firms' $10-\mathrm{Ks} / 10-\mathrm{Qs}$ and amended $10-\mathrm{Ks} / 10-\mathrm{Qs}$ as well as from information provided by the individual firms.

The GAO restatement firm database is then merged with Compustat's Executive Compensation (ExecuComp, hereafter) database to ensure that management-related data are available to include in the Index. The data are further merged with the database compiled by the Investor Responsibility Research Center (IRRC, hereafter). IRRC data are taken from publicly-available 1996-2004 proxy statements issued in anticipation of the annual meetings for the S\&P 1500 companies. The data include characteristics pertaining to the board of directors and are thus utilized in the calculation of the Index.

These datasets combine to obtain 254 restatements by 225 unique firms. In order to perform the analysis, data must be available in both the pre-restatement and post-restatement periods. Because of this requirement, the sample is reduced to 140 restatements. An additional three observations are further eliminated due to missing data regarding the restatement duration and magnitude, yielding 137 restatements in the final sample.

Panel A of Table 1 presents a reconciliation of the sample, and Panel B presents the control sample. The control sample consists of all non-restatement firms (i.e., non-GAO firms) over the period 1996 - 2004 appearing in both the ExecuComp and IRRC databases. Table 1, Panel B provides a distribution of control sample firms across the years 1996 - 2004. The number of firms with available data increases slightly each year from 949 in 1996 to 1,262 in 2004.

Panel A of Table 2 presents the yearly distribution of sample restatements. Although the sample period extends from the beginning of 1997 through June 2002, the vast majority of the restatements (71\%) are announced between the years 1999 and 2001, in part due to the SEC initiatives to restate IPR\&D charges and to adopt new revenue recognition rules under SAB101, in late 1998 and late 1999, respectively. Table 2, Panel B provides the distribution of sample restatements across firms. Because of several cases of multiple restatements by firms, the 137 sample restatements are issued by 121 unique firms. Multiple restatements by firms are analyzed independently, each one presenting its own set of circumstances. Finally, Panel C of Table 2 provides the industry distribution of sample restatements. With more than $37 \%$ of the restatements, manufacturing is the most frequently occurring industry in the sample. Using the same industry classification system, manufacturing is also the industry with the greatest number of Compustat firms (32.5\%), implying that this finding is consistent.

Descriptive statistics for sample restatements are presented in Table 3. Based on the GAO Report, Panel A itemizes the sample by initiator of the restatement, exchange listing of the restatement firm, and reason for the announced restatement. In addition, the sample is classified by the presence or absence of fraud based on company admission of misstatement due to fraud/irregularities or based on issuance of an enforcement action (AAER) by the SEC. The Lexis-Nexis Academic Universe is searched by restatement firm name for occurrences of AAERs in all years subsequent to the announced restatement. The circumstances surrounding each AAER are carefully studied to determine whether fraudulent behavior by the firm prompted the SEC action. ${ }^{16}$

\footnotetext{
${ }^{16}$ AAERs are generally quite explicit in specifying the targets and causes of the enforcement action. Therefore, based on the timeline and stated details of each AAER, it is relatively objective to ascertain whether it was fraudulent behavior by the firm that prompted the SEC action.
} 
Table 1: Sample Selection and Control Sample

Panel A: Sample selection of 137 restatements in the period 1997 - June 2002

$\begin{array}{lc}\text { Restriction } & \text { Sample Size } \\ 1997 \text { - June } 2002 \text { (GAO database) } & 919\end{array}$

Number of restatements in the period 1997 - June 2002 (GAO database)

919

Less:

Firms without data in both the S\&P ExecuComp

and IRRC (Investor Responsibility Research Center) databases (1996-2004) $665 \quad \underline{254}$

Observations without data for the pre- or post-restatement period

114

$\underline{140}$

Observations with missing restatement severity data

3

Final restatement sample

Panel B: Control sample: non-restatement firms

\begin{tabular}{ccc}
\hline Year & Number of Firms & Percentage of Total \\
\hline 1996 & 949 & $8.8 \%$ \\
1997 & 1,099 & $10.2 \%$ \\
1998 & 1,202 & $11.2 \%$ \\
1999 & 1,214 & $11.3 \%$ \\
2000 & 1,217 & $11.3 \%$ \\
2001 & 1,284 & $11.9 \%$ \\
2002 & 1,255 & $11.7 \%$ \\
2003 & 1,285 & $11.9 \%$ \\
2004 & 1,262 & $11.7 \%$ \\
& & $100 \%$ \\
\hline
\end{tabular}

Table 2: Descriptive Statistics for Distribution of Sample Restatements by Year, Firm, and Industry Panel A: Yearly distribution of restatements

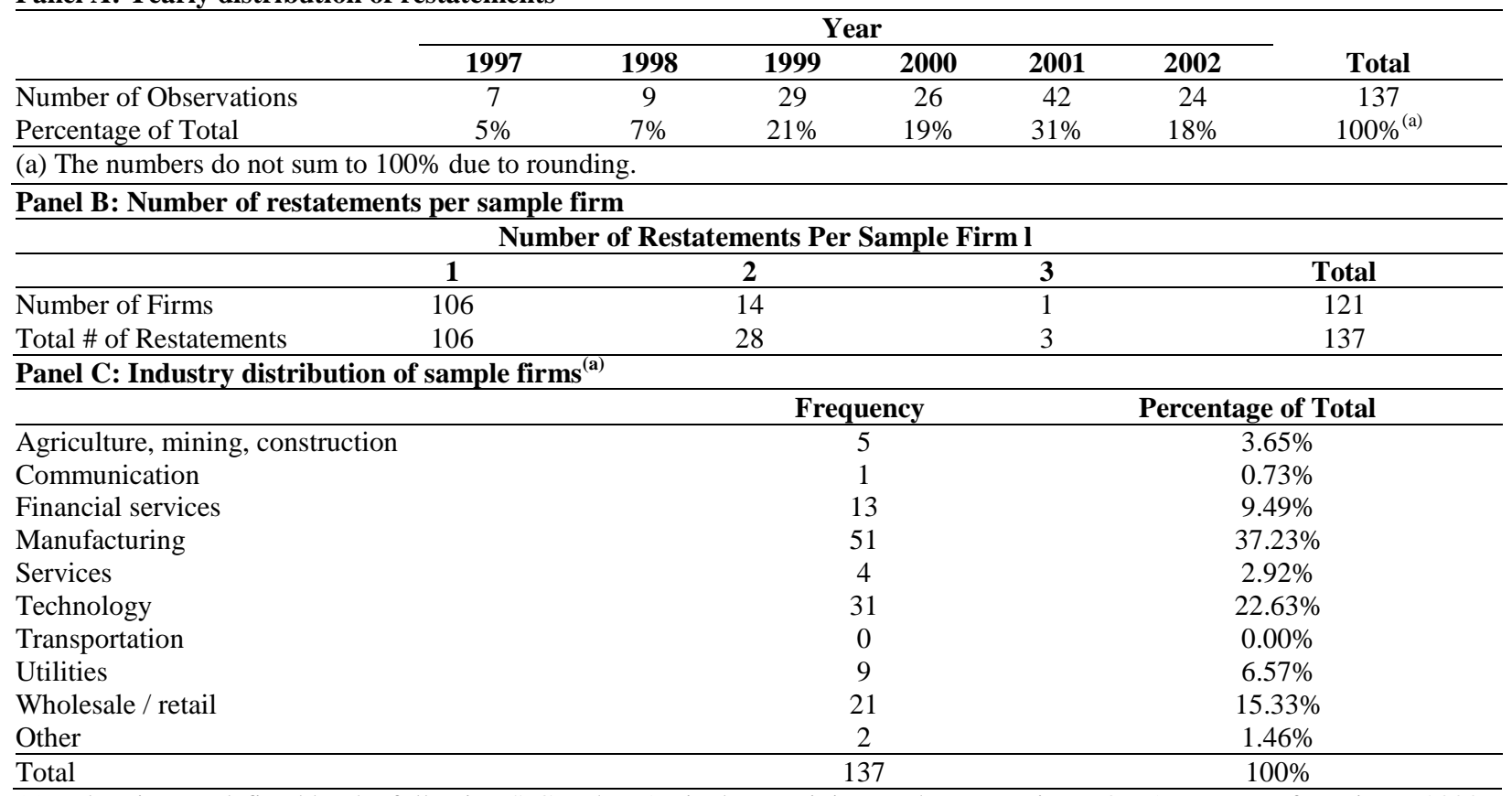

(a) Industries are defined by the following SIC codes: Agriculture, mining, and construction = 0 - 1999; Manufacturing = 2000 3999 (except codes assigned to Technology); Technology = $3570-3579$ plus $7370-7379$; Transportation $=4000-4799$; Communications $=4800-4899 ;$ Utilities $=4900-4999 ;$ Wholesale $/$ retail $=5000-5999 ;$ Financial services $=6000-6999 ;$ Services $=7000-8999$ (except codes assigned to Technology). Industry classification is taken from Palmrose and Scholz (2004). 
While auditor-initiated restatements account for the smallest portion of the sample (4\%), $30 \%$ of the identified sample restatements are initiated by the company, and $25 \%$ are initiated by the SEC. The majority of the restatements in the sample are announced by NYSE-listed firms (75.2\%), reflecting the fact that the sample restatements are made by relatively large companies. Of the total control sample, 66\% are NYSE-listed firms, as compared to $36.6 \%$ of all Compustat firms. This indicates that it is the sample selection that leads to the largecompany bias. Fraud is associated with $28 \%$ of the sample restatements. This is roughly comparable to the $21 \%$ identified by Palmrose et al. (2004) in their restatement sample. Finally, revenue recognition is identified as the reason for restatement in $44 \%$ of the sample, which is comparable to the findings of the GAO Report. ${ }^{17}$

\section{Panel A: Restatement characteristics}

Table 3: Descriptive Statistics for Sample Restatements

\begin{tabular}{|c|c|c|}
\hline & Frequency & Percentage of Total \\
\hline Full Sample & 137 & $100 \%$ \\
\hline \multicolumn{3}{|l|}{ Prompter $^{(a)}$} \\
\hline Auditor & 6 & $4 \%$ \\
\hline Company & 41 & $30 \%$ \\
\hline SEC & 34 & $25 \%$ \\
\hline Other & 56 & $41 \%$ \\
\hline \multicolumn{3}{|l|}{ Exchange Listing $^{(a)}$} \\
\hline AMEX & 1 & $0.7 \%$ \\
\hline NASDAQ & 33 & $24.1 \%$ \\
\hline NYSE & 103 & $75.2 \%$ \\
\hline \multicolumn{3}{|l|}{$A A E R /$ Fraud $^{(b)}$} \\
\hline Yes & 39 & $28 \%$ \\
\hline No & 98 & $72 \%$ \\
\hline \multicolumn{3}{|l|}{ Reason $^{(a)(c)}$} \\
\hline Cost or expense & 21 & $15 \%$ \\
\hline In-process R\&D & 8 & $6 \%$ \\
\hline Loan-loss & 3 & $2 \%$ \\
\hline Mergers and acquisitions & 14 & $10 \%$ \\
\hline Reclassification & 6 & $4 \%$ \\
\hline Related-party transactions & 8 & $6 \%$ \\
\hline Restructuring, assets, or inventory & 23 & $17 \%$ \\
\hline Revenue recognition & 60 & $44 \%$ \\
\hline Securities related & 3 & $2 \%$ \\
\hline Unspecified & 5 & $4 \%$ \\
\hline Other & 12 & $9 \%$ \\
\hline
\end{tabular}

(a) This breakdown is based on the GAO Report (2002).

(b) AAER/Fraud is defined as in Palmrose et al. (2004) as the issuance of an enforcement action (AAER) by the SEC or company disclosures of fraud/irregularities.

(c) A number of restatements are coded with multiple reasons. Therefore, the percentages listed do not sum to $100 \%$.

Panel B of Table 3 describes the restatements that are identified as revenue-related in further detail. Restatements triggered by the SEC adoption of revenue recognition rules under SAB101 and those resulting from guidance by a FASB EITF account for equal shares of the sample (32\% each). The remainder of the sample (about $37 \%$ ) comprises all remaining revenue-related restatements, such as those resulting from improperly recorded or overstated sales, understated costs of goods sold and other expenses, and timing of revenue recognition issues.

\footnotetext{
${ }^{17}$ The GAO Report identifies revenue recognition as the reason for restatement in $38 \%$ of the restatements analyzed.
} 
Table 3: Panel B: Revenue recognition restatements

\begin{tabular}{ccc}
\hline & Frequency & Percentage of Total \\
\hline Revenue recognition & 60 & $100 \%^{(\mathrm{a})}$ \\
${\text { SAB } 101^{(\mathrm{b})}}_{\text {EITF }^{(\mathrm{c})}}$ & 19 & $32 \%$ \\
Other & 19 & $32 \%$ \\
\hline
\end{tabular}

(a) The numbers do not sum to $100 \%$ due to rounding.

(b) SAB101 refers to restatements resulting from the SEC adoption of revenue recognition rules under Staff Accounting Bulletin No. 101 (SAB101).

(c) EITF refers to restatements resulting from guidance by a FASB Emerging Issues Task Force (EITF).

Panel C of Table 3 reports some further descriptive statistics for the sample restatements. The mean (median) restatement amount is $-\$ 353.6(-\$ 4.9)$ million. This is calculated by subtracting originally reported net income (in millions) from restated net income (summed over all restated periods). The magnitude of the restatement measures the restatement amount as a percentage of the firm's total assets at the year-end prior to the restatement announcement. The mean (median) magnitude for the sample is $-2.3 \%(-0.16 \%)$. These numbers are consistent with the notion that, on average, it is income-decreasing restatements that are required to correct prior misstatements of net income, often due to intentional manipulation. The duration of the restatement, measured as the number of quarters restated, has a mean (median) value of 6.3 (4.0). This is similar to findings by Palmrose et al. (2004) and Srinivasan (2005), among others.

As in Palmrose et al. (2004), a market-adjusted model based on an equally weighted index (with dividends) is used to estimate abnormal returns. This model subtracts the CRSP market index return from a firm's daily return to obtain the market-adjusted abnormal return for each day and firm. The daily abnormal returns are summed to calculate the cumulative abnormal return (CAR, hereafter) for a given time period. The mean (median) marketadjusted CAR, using an equally weighted index over the 2-day window beginning on day 0 , the day of the restatement announcement, is $-5.0 \%(-2.7 \%) .{ }^{18}$ This is comparable to results in Agrawal and Chadha (2005) but slightly lower than results in Palmrose et al. (2004). ${ }^{19}$ Finally, the panel confirms that the sample firms are relatively large. The mean (median) total assets at the year-end prior to the restatement announcement is $\$ 9,101(\$ 2,513)$ million.

Table 3: Panel C: Further descriptive statistics

\begin{tabular}{llccc}
\hline & Mean & Q1 & Median & Q3 \\
\hline Restatement amount (in \$ millions) & -353.6 & -27.0 & -4.9 & 0 \\
Magnitude (scaled by total assets) & $-2.3 \%$ & $-0.8 \%$ & $-0.16 \%$ & $0 \%$ \\
Duration (number of quarters) & 6.3 & 3 & 4 & 8 \\
Announcement return (0,1) & $-5.0 \%$ & $-10.1 \%$ & $-2.7 \%$ & $1.0 \%$ \\
Size of firm (total assets in \$ millions) & 9,101 & 836 & 2,513 & 9,536 \\
\hline
\end{tabular}

(a) The announcement return is defined as the market-adjusted cumulative abnormal return (equally weighted index) over days 0 and 1 , where day 0 is the restatement announcement date.

\section{CONSTRUCTION OF THE DEPENDENT VARIABLE}

The dependent variable, Index-Change, is derived through a number of steps from data collected from the IRRC, Compustat, and ExecuComp databases. The IRRC database provides information on the board of directors, Compustat provides data on audit variables, and ExecuComp provides data on management-related variables. Based on the data collection, an Index is calculated for the firm in each sample restatement in the year preceding the restatement announcement (pre-restatement period) and then again two years following the restatement (post-

\footnotetext{
${ }^{18}$ As in Palmrose et al. (2004), the announcement effect occurs primarily on days 0 and +1 . The mean (median) CAR over a three-day window beginning one day prior to the restatement announcement (day -1$)$ is $-5.0 \%(-3.3 \%)$.

${ }^{19}$ Agrawal and Chadha (2005) report the CAR over a three-day window to have a mean (median) of $-5.7 \%$ $(-2.5 \%)$. Palmrose et al. (2004) find the 2-day CAR to have a mean (median) of $-9.2 \%(-4.6 \%)$.
} 
restatement period). As discussed earlier, the Index is a composite score computed based on an array of governance features, including board, audit, and management-related variables.

Table 4 describes the variables included in the Index. Variables 1-10 relate to the board of directors, variables 11-12 concern the external auditor, and variable 13 relates to the top management (CEO) of the firm. Table 5 presents descriptive statistics for the components of the Index. Panel A reports statistics for a reduced control sample of 7,517 firm-year observations beginning in 1999. The purpose of the reduced control sample is to facilitate comparison with the Index variables of sample restatements in the post-restatement period. For restatements in the sample $(1997$ - 2002), the post-restatement period refers to the years 1999 - 2004. Because statistics are undoubtedly linked to the time period, it is imperative to view the post-restatement period of restatement firms with regard to a contemporaneous control sample.

Panel B provides summary statistics for the post-restatement period of the 137 sample restatements. A comparison between Panels A and B highlights a number of differences between the control and restatement samples. In particular, the difference in means is statistically significant for the fraction of independent directors on the board as well as various board sub-committees, the size of the board, whether the board chair is an independent outside director, and whether there is a change in CEO over the prior three years. ${ }^{20}$

Table 4: Description of Index Variables

\begin{tabular}{|c|c|}
\hline Variable Name & Variable Description \\
\hline bd-ind & Fraction of independent directors on the board. \\
\hline dual-CEO & 1 if the CEO is not the board chair; zero, otherwise. \\
\hline indep-chair & 1 if an independent outside director is the board chair; zero, otherwise. \\
\hline audit-indep & Fraction of independent directors on the audit committee. \\
\hline comp-indep & Fraction of independent directors on the compensation committee. \\
\hline nom-indep & Fraction of independent directors on the nominating committee. \\
\hline corpgov-indep & Fraction of independent directors on the corporate governance committee. \\
\hline bd-size & Number of board members. \\
\hline interlock & Fraction of interlocked directors on the board. \\
\hline other-boards & $\begin{array}{l}\text { Total number of other companies' boards served by all directors, divided by total number of } \\
\text { board members. }\end{array}$ \\
\hline auditor-big6 & 1 if the firm is audited by a Big Six firm; zero, otherwise. \\
\hline auditor-switch & 1 if there is a change in auditor; zero, otherwise. \\
\hline CEO-switch & 1 if there is a change in CEO; zero, otherwise. \\
\hline Index-Pre & Total Index in the pre-restatement period (year $\mathrm{t}-1$ ). \\
\hline Index-Post & Total Index in the post-restatement period (year $\mathrm{t}+2)$. \\
\hline \multicolumn{2}{|c|}{$\begin{array}{l}\text { The Index can range from } 0 \text { to } 13 \text {. The Index increases by one if: (1) more than two-thirds of the board is comprised of } \\
\text { independent directors; (2) the CEO is not also Chairman of the Board; (3) the Chairman of the Board is an independent outside } \\
\text { director; (4) all audit committee members are independent directors; (5) all compensation committee members are independent } \\
\text { directors; (6) all nominating committee members are independent directors; ( } 7 \text { ) all corporate governance committee members } \\
\text { are independent directors; (8) the board size is less than the median of all firms (adjusted for firm size and time); (9) the board } \\
\text { interlock is less than the median of all firms (adjusted for firm size and time); (10) the mean number of other boards served by a } \\
\text { director is less than the median of all firms (adjusted for firm size and time); (11) the firm is audited by a Big Six firm; (12) } \\
\text { there is a change in the external auditor within the last three years; (13) there is a change in the CEO within the last three years. } \\
\text { To adjust for firm size and time, the measure is computed net of the median for the particular year and firm size decile. }\end{array}$} \\
\hline
\end{tabular}

\footnotetext{
${ }^{20}$ Although these statistically significant differences in Index variables are meaningful, it should be noted that additional controls for the time period are necessary, since sample restatements are not evenly distributed across the years. In further analyses, these additional controls are implemented.
} 
Table 5: Descriptive Statistics for Index Variables

\begin{tabular}{lcccccc}
\hline \multicolumn{2}{l}{ Panel A: Control sample (non-restatement firms): $\mathbf{1 9 9 9}-\mathbf{2 0 0 4}^{\text {(a) }}$} & & & \\
\hline & Mean & Median & Minimum & Maximum & Std. Dev. & N \\
\hline bd-ind & 0.653 & 0.667 & 0.100 & 1.000 & 0.171 & 7,451 \\
dual-CEO & 0.341 & 0.000 & 0.000 & 1.000 & 0.474 & 7,517 \\
indep-chair & 0.614 & 1.000 & 0.000 & 1.000 & 0.487 & 7,517 \\
audit-indep & 0.900 & 1.000 & 0.200 & 1.000 & 0.175 & 7,407 \\
comp-indep & 0.908 & 1.000 & 0.143 & 1.000 & 0.174 & 7,302 \\
nom-indep & 0.833 & 0.667 & 0.167 & 1.000 & 0.216 & 5,420 \\
corpgov-indep & 0.874 & 1.000 & 0.200 & 1.000 & 0.188 & 3,671 \\
bd-size & 9.450 & 9.000 & 1.000 & 28.000 & 2.914 & 7,451 \\
interlock & 0.010 & 0.000 & 0.000 & 0.500 & 0.034 & 7,411 \\
other-boards & 0.856 & 0.700 & 0.000 & 2.900 & 0.891 & 7,376 \\
auditor-big6 & 0.978 & 1.000 & 0.000 & 1.000 & 0.147 & 6,896 \\
auditor-switch & 0.223 & 0.000 & 0.000 & 1.000 & 0.416 & 6,168 \\
CEO-switch & 0.326 & 0.000 & 0.000 & 1.000 & 0.469 & 5,596 \\
\hline (a) Desciptive & stat &
\end{tabular}

(a) Descriptive statistics are for the 7,517 firm-year control observations over the period $1999-2004$. Depending on data availability, there is some variation in the total number of firm-year observations for each variable.

Panel B: Restatement firms in the post-restatement period ${ }^{(\mathbf{b})}$

\begin{tabular}{lcccccc}
\hline & Mean & Median & Minimum & Maximum & Std. Dev. & N \\
\hline bd-ind & $0.681^{*}$ & 0.714 & 0.152 & 0.938 & 0.175 & 136 \\
dual-CEO & 0.294 & 0.000 & 0.000 & 1.000 & 0.457 & 136 \\
indep-chair & $0.743^{*}$ & 1.000 & 0.000 & 1.000 & 0.439 & 136 \\
audit-indep & $0.912^{*}$ & 1.000 & 0.333 & 1.000 & 0.154 & 135 \\
comp-indep & $0.919^{*}$ & 1.000 & 0.250 & 1.000 & 0.159 & 132 \\
nom-indep & $0.841^{*}$ & 1.000 & 0.222 & 1.000 & 0.215 & 115 \\
corpgov-indep & $0.875^{*}$ & 1.000 & 0.222 & 1.000 & 0.181 & 92 \\
bd-size & $10.000^{*}$ & 10.000 & 5.000 & 33.000 & 3.209 & 136 \\
Interlock & 0.007 & 0.000 & 0.000 & 0.200 & 0.028 & 109 \\
other-boards & 0.978 & 0.905 & 0.000 & 2.846 & 0.640 & 114 \\
auditor-big6 & 0.984 & 1.000 & 0.000 & 1.000 & 0.124 & 129 \\
auditor-switch & 0.233 & 0.000 & 0.000 & 1.000 & 0.424 & 129 \\
CEO-switch & $0.458^{*}$ & 0.000 & 0.000 & 1.000 & 0.500 & 131 \\
\hline
\end{tabular}

* Significant at the $1 \%$ level, based on a two-tailed z-test for the difference in means between the post-restatement period for 137 sample restatements and the control firms during a corresponding time period (1999 - 2004).

(b) Descriptive statistics are for the 137 sample restatements. Depending on data availability, there is some variation in the total number of observations for each variable.

As discussed in Section 2, the Index is calculated for the pre- and post-restatement periods for each sample restatement by assigning a 0 or 1 to each variable based on specific guidelines. Table 4 reviews the specifications for each variable. Although the Index can in theory range from 0 to 13, due to data limitations, the sample firms have a maximum Index of anywhere between 3 and 13 (mean $=10.84$; median $=11)$. In cases where the variables available for calculation of the Index differ between the pre-restatement and post-restatement periods, only those variables that are common to both periods are included in each Index. This eliminates any potential biases regarding data availability. The Index Percentage refers to the Index divided by the total number of variables available. Variables 1-11 can take on a value of either 0 or 1 . However, variables 12-13 always have a value of 0 in the pre-restatement period and can only vary (between 0 and 1 ) in the post-restatement period.

As described in Section 2, the dependent variable, Index-Change, refers to the percentage change between the Index in the pre-restatement period and the Index in the post-restatement period. ${ }^{21}$

Table 6 provides some descriptive statistics for the overall Index Percentage in the pre- and postrestatement periods and then for Index-Change, which represents the change in the Index between the two periods.

\footnotetext{
${ }^{21}$ Because the denominator of the Index Percentage is the same in both the pre- and post-restatement periods, there is no concern for the denominator when calculating Index-Change.
} 
Panel A compares the Index Percentage among sample restatements in the pre-restatement period (year $\mathrm{t}-1$ ) with a sample that matches the median Index Percentage in the same industry-year among the control sample of nonrestatement firms to each sample restatement. Sample restatements exhibit lower levels of Index Percentage across all quartiles, and the difference in means is statistically significant at the $1 \%$ level $(0.486$ among sample restatements versus 0.540 among the control sample). Panel B reports that the Index Percentage among sample restatements in the post-restatement period (year $\mathrm{t}+2$ ) is higher than the Index Percentage in the pre-restatement period (year $\mathrm{t}-1$ ) across all quartiles. Furthermore, with a mean Index Percentage of 0.580 in year $\mathrm{t}+2$ and 0.486 in year $\mathrm{t}-1$, the difference in means between the two periods is statistically significant $(\mathrm{t}-\mathrm{stat}=-5.08 ; \mathrm{p}<.0001)$.

Table 6: Descriptive Statistics for Index Percentage, Index-Change, and Index-Change-Control

Panel A: Index Percentage in year $\mathrm{t}-1$

\begin{tabular}{lcccc} 
& \multicolumn{3}{c}{ Index Percentage } & \\
\cline { 3 - 5 } & Mean & Q1 & Median & Q3 \\
\hline Restatement Firms (Sample) & .486 & .375 & .500 & .583 \\
Non-restatement Firms (Control) & .540 & .500 & .545 & .600 \\
(t-stat) & $(-3.75)^{*}$ & & & \\
$\mathrm{~N}$ & 137 & & &
\end{tabular}

* Significant at the $1 \%$ level, based on a two-tailed t-test for the difference in means between the Index Percentage among sample restatements in the pre-restatement period and a sample of the matched median Index Percentage values in the same industry-year in non-restatement firms (control sample).

Panel B: Index Percentage in years $\mathrm{t}-1$ and $\mathrm{t}+2$

\begin{tabular}{|c|c|c|c|c|}
\hline \multirow[b]{2}{*}{ Year Relative to the Restatement } & \multicolumn{3}{|c|}{ Index Percentage } & \multirow[b]{2}{*}{ Q3 } \\
\hline & Mean & Q1 & Median & \\
\hline Pre-restatement $(\mathrm{t}-1)$ & .486 & .375 & .500 & .583 \\
\hline $\begin{array}{l}\text { Post-restatement }(t+2) \\
(t-s t a t)\end{array}$ & $\begin{array}{c}.580 \\
(-5.08)^{*}\end{array}$ & .455 & .583 & .667 \\
\hline $\mathrm{N}$ & 137 & & & \\
\hline
\end{tabular}

* Significant at the $1 \%$ level, based on a two-tailed t-test for the difference in means between years $\mathrm{t}-1$ and $\mathrm{t}+2$.

As discussed in Section 3, Index-Change-Control is used to control for "normal" changes in the Index over a three-year period. Each sample restatement is matched to the median Index-Change for the corresponding industry-year in non-restatement firms (control sample). ${ }^{22}$ Panel C of Table 6 compares statistics between IndexChange and Index-Change-Control. The difference in mean values between the two variables is statistically significant ( $\mathrm{t}$-stat $=3.72 ; \mathrm{p}<.0001$ ). The implication is that changes to the Index appear to be more pronounced among sample restatement firms than in the control sample of non-restatement firms.

Table 6: Panel C: Index-Change and Index-Change-Control

\begin{tabular}{lcccc}
\hline & Mean & Q1 & Median & Q3 \\
\hline Index-Change & .331 & .000 & .167 & .500 \\
Index-Change-Control & .120 & .043 & .100 & .143 \\
(t-stat) & $(3.72)^{*}$ & & & \\
$\mathrm{~N}$ & 137 & & & \\
\hline
\end{tabular}

* Significant at the $1 \%$ level, based on a two-tailed t-test for the difference in means between Index-Change and Index-ChangeControl.

\footnotetext{
${ }^{22}$ The calculation of the Index in non-restatement firms is similar to the calculation in sample firms, with the following exceptions: (1) all available data are used for the calculation each year; (2) all variables can take on values of either 0 or 1 in any given year. To calculate Index-Change in non-restatement firms, the following method is employed. For each firm-year, the Index is divided by the total number of variables available. This creates an Index Percentage and allows for changes in data availability. For each firm-year, Index-Change is then calculated as the percentage change in the Index Percentage over the prior three years.
} 


\section{EMPIRICAL RESULTS FOR A SAMPLE HYPOTHESIS}

Table 7 defines the variables as they are used in the analysis that follows. The dependent variable, sample test variable, and control variables are described in the table.

Table 7: Variable Definitions

\begin{tabular}{|c|c|}
\hline \multicolumn{2}{|l|}{ Dependent Variable: } \\
\hline Index-Change & Index-Post / Index-Pre-1 \\
\hline \multicolumn{2}{|l|}{ Sample Test Variable: } \\
\hline$A A E R$ & $\begin{array}{l}1 \text { if the SEC issued an enforcement action (Accounting and Auditing Enforcement } \\
\text { Release) or the company admitted that the misstatement was due to fraud/irregularities; } \\
\text { zero, otherwise. }\end{array}$ \\
\hline \multicolumn{2}{|r|}{ (1) } \\
\hline Pre & $\begin{array}{l}\text { The governance level in the pre-restatement period, calculated as the fraction represented } \\
\text { by the Index divided by the maximum Index for that firm-year, less the median } \\
\text { governance level in the same industry-year in non-restatement firms (control sample). }\end{array}$ \\
\hline Gov-Control & $\begin{array}{l}\text { The median governance level in the pre-restatement period in the same industry-year in } \\
\text { non-restatement firms (control sample). }\end{array}$ \\
\hline Index-Change-Control & $\begin{array}{l}\text { The median Index-Change over the prior three years in the same industry-year in non- } \\
\text { restatement firms (control sample), where an industry is defined by its } 2 \text {-digit SIC code. }\end{array}$ \\
\hline
\end{tabular}

Table 8 presents cross-sectional results for the following equation:

$$
\begin{aligned}
\text { Index-Change }=\quad & \beta_{0}+\beta_{1} \text { Pre }+\beta_{2} \text { Gov-Control } \\
& +\beta_{3} \text { Index-Change-Control }+\beta_{4} A A E R+\varepsilon
\end{aligned}
$$

This equation is based on the theoretical model and sample hypothesis developed in Section 3. The generalized form of this model follows:

$$
\begin{aligned}
\text { Index-Change }=\quad & \beta_{0}+\beta_{1} \text { Pre }+\beta_{2} \text { Gov-Control } \\
& +\beta_{3} \text { Index-Change-Control }+\beta_{4} X+\varepsilon
\end{aligned}
$$

where $X$ refers to any test variable (i.e. restatement or firm characteristic) predicted to explain Index-Change in a specific way. Pre and Gov-Control are control variables included in the model to control for pre-restatement governance levels. Index-Change-Control is included in the model as well because of its importance in controlling for industry and year effects. To control for the "normal" changes in the Index over a three-year period, IndexChange-Control matches each sample restatement with the median Index-Change for the corresponding industryyear in non-restatement firms.

Table 8: Regression Results

\begin{tabular}{lccr}
\hline Index-Change on AAER & & & \\
\hline Independent Variables & Expected Sign & Coefficient & t-statistic \\
\hline Intercept & - & 2.410 & $(5.07)^{* * * *}$ \\
Pre & - & -2.719 & $(-9.70)^{* * * *}$ \\
Gov-Control & + & -4.206 & $(-5.21)^{* * *}$ \\
Index-Change-Control & + & -0.183 & $(-0.41)$ \\
AAER & & 0.230 & $(2.53)^{* *}$ \\
& & & 137 \\
Model Statistics & & $47 \%$ & \\
$N$ & & $30.78^{* * *}$ & \\
Adjusted $R^{2}$ & & \\
$F$-statistic & &
\end{tabular}

$* *, * * *$ Significant at the $5 \%$ and $1 \%$ levels, respectively. 
Results in Table 8 show that as predicted by the Sample Hypothesis, the coefficient of AAER is significant at the $5 \%$ level in explaining changes to firms' governance mechanisms in the post-restatement period. Firms are more likely to implement corporate governance changes following restatements involving fraud. Coefficients of Pre and Gov-Control are highly significant at the $1 \%$ level, and the model's adjusted $\mathrm{R}^{2}$ is $47 \%$.

\section{CONCLUSIONS}

This paper conducts an analysis on a sample of 137 restatements issued by 121 unique U.S. firms over the period January 1997 through June 2002. It provides a detailed classification of the sample on the basis of presence of fraud, prompter, magnitude, severity, and reason for the restatement. It develops the Index, an innovative research tool designed to investigate whether a correlation exists between restatement characteristics and steps taken by firms to improve their governance mechanisms in the period following a restatement. This Index, calculated as a composite score based on an array of governance features, including board, audit, and management-related variables measures the joint strength of multiple corporate governance attributes within a firm. The Index is calculated for each firm in the year preceding the restatement announcement and then again two years following the restatement. The paper demonstrates how a comparison of the Index between the two periods may be used to relate the nature and magnitude of a restatement with the likelihood of corporate governance changes in the aftermath of restatement.

To illustrate the use of the Index in the research model, a sample hypothesis is examined. As expected, results show a statistically significant association between restatements involving fraud and changes aimed to strengthen firms' governance structures following the restatements.

In view of the prevalence of earnings restatements in recent years, this study is both timely and important. While consequences to restatement firms can be quite severe, governance changes do not necessarily follow restatements. It is possible that entrenched and/or overconfident managers may choose not to undertake improvements. Also, relatively more technical restatements, such as those that arise in response to official guidance, may be less likely to provide incentive to restatement firms to implement changes.

This study contributes to the literature in two major ways. First, the more detailed classification of GAO restatements sets the stage for further analysis by recognizing that responses to restatements likely relate to particular characteristics of the restatement. Second, the paper develops a research model designed to relate the nature and magnitude of a restatement with the likelihood of corporate governance changes in the post-restatement period.

Future research is needed to use the methodology outlined in this paper to conduct further tests and determine additional results of restatements. This would have definite implications for investors as well as regulators. For example, investors can be comforted by the finding that restatements involving financial statement fraud "force" firms to correct underlying problems by implementing changes in their governance arrangements. Under such circumstances, firms appear to understand the value in strengthening their corporate governance. Similarly, further findings are necessary to ascertain which restatement characteristics are associated with governance improvements. Where restatements are found less likely to effect governance changes, regulation may be beneficial. On the other hand, it would be prudent for regulators to consider the nature and magnitude of the restatement. For instance, intervention may seem unnecessary in cases of relatively more technical restatements, such as those that arise due to official guidance, or those that are relatively less severe in terms of their effect on firms' financial statements.

This study has implications for several other lines of future research. First, future research may look to address alternative formulations of the Index. For instance, the inclusion of other governance variables would add to the robustness of the Index as a measure for the overall strength of a firm's corporate governance. Furthermore, weighting component features of the Index using a systematic method might yield added insight regarding firms' decisions to implement changes to their governance mechanisms. 


\section{AUTHOR INFORMATION}

Aliza Rotenstein is an assistant professor of accounting in the Sy Syms School of Business at Yeshiva University. She holds a PhD in business/accounting from the CUNY Graduate Center and teaches courses in financial and management accounting. Her main research interests include corporate governance, accounting restatements, and earnings management, and she is currently involved in research projects relating to accounting education and accounting for non-profit organizations. Her research has appeared in the Journal of Accounting Education and the Journal of Business Case Studies.

\section{REFERENCES}

1. Abbott, L.J, Parker, S., and G.F. Peters. 2004. "Audit committee characteristics and restatements." Auditing: A Journal of Practice and Theory 23: 69-87.

2. Agrawal, A. and S. Chadha. 2005. "Corporate governance and accounting scandals." Journal of Law and Economics 48: 371-406.

3. Agrawal, A. and C.R. Knoeber. 1996. "Firm performance and mechanisms to control agency problems between managers and shareholders." Journal of Financial and Quantitative Analysis 31: 377-397.

4. Anderson, K.L. and T.L. Yohn. 2002. "The effect of 10-K restatements on firm value, information asymmetries, and investors' reliance on earnings." Working paper, Georgetown University.

5. Baber, W.R., Kang, S., Liang, L., and Z. Zhu. 2009. "Shareholder rights, corporate governance, and accounting restatement." Working paper, George Washington University.

6. Baysinger, B.D. and H.N. Butler. 1985. "Corporate governance and board of directors: performance effects of changes in board composition." Journal of Law, Economics, and Organization 1: 101-124.

7. Beasley, M.S. 1996. "An empirical analysis of the relation between the board of director composition and financial statement fraud." Accounting Review 71: 443-465.

8. Benston, G.J. 1985. "The self-serving management hypothesis: Some evidence.” Journal of Accounting and Economics 7: 67-84.

9. Bhagat, S. and B. Black. 1999. "The uncertain relationship between board composition and firm performance. The Business Lawyer 54: 921-963.

10. Brickley, J.A., Coles, J.L., and G. Jarrell. 1997. "Leadership structure: Separating the CEO and chairman of the board." Journal of Corporate Finance 3: 189-220.

11. Burns, N. and S. Kedia. 2006. "The impact of performance-based compensation on misreporting." Journal of Financial Economics 79: 35-67.

12. Cheng, Q. and D.B. Farber. 2008. "Earnings restatements, changes in CEO compensation, and firm performance." The Accounting Review 83: 1217-1250.

13. Collins, D., Reitenga, A.L., and J.M. Sanchez-Cuevas. 2008. "The impact of accounting restatements on CFO turnover and bonus compensation: Does securities litigation matter?" Advances in Accounting 24: 162-171.

14. Conyon, M.J. and A. Florou. 2002. "Top executive dismissal, ownership, and corporate performance." Accounting and Business Research 32: 209-225.

15. Core, J.E., Holthausen, R.W., and D.F. Larcker. 1999. "Corporate governance, CEO compensation, and firm performance. Journal of Financial Economics 51: 371-390.

16. Cotter, J.F., Shivdasani, A., and M. Zenner. 1997. "Do independent directors enhance target shareholder wealth during tender offers?" Journal of Financial Economics 43: 195-219.

17. Coughlan, A.T. and R.M. Schmidt. 1985. "Executive compensation, management turnover, and firm performance." Journal of Accounting and Economics 7: 43-66.

18. Dahya, J., McConnell, J.J., and N.G. Travlos. 2002. "The Cadbury Committee, corporate performance, and top management turnover." Journal of Finance 57: 461-483.

19. DeAngelo, L. 1981. "Auditor size and audit quality." Journal of Accounting and Economics 3: 183-199.

20. Dechow, P.M., Sloan, R.G., and A.P. Sweeney. 1995. "Detecting earnings management.” The Accounting Review 70: 193-225.

21. 1996. "Causes and consequences of earnings manipulation: An analysis of firms subject to enforcement actions by the SEC.” Contemporary Accounting Research 13: 1-36. 
22. Denis, D.J., and D.K. Denis. 1995. "Performance changes following top management dismissals." Journal of Finance 50: 1029-1057.

23. Desai, H., Hogan, C.E., and M.S. Wilkins. 2006. "The reputational penalty for aggressive accounting: Earnings restatements and management turnover." The Accounting Review 81: 83-112.

24. Farber, D.B. 2005. "Restoring trust after fraud: Does corporate governance matter?" The Accounting Review 80: 539-561.

25. Feroz, E.H., Park, K., and V.S. Pastena. 1991. "The financial and market effects of the SEC's accounting and auditing enforcement releases." Journal of Accounting Research 29: 107-142.

26. Fich, E.M and L.J. White. 2003. "CEO compensation and turnover: the effects of mutually interlocked boards." Wake Forest Law Review 38: 935-959.

27. Franks, J. and C. Mayer. 1996. "Hostile takeovers and the correction of managerial failure." Journal of Financial Economics 40: 163-181.

28. Furtado, E.P.H. and V. Karan. 1990. "Causes, consequences, and shareholder wealth effects of management turnover: A review of empirical evidence." Financial Management 19: 60-75.

29. G.A.O. 2002. "Financial statement restatements: Trends, market impacts, regulatory responses, and remaining challenges." GAO-03-138, United States General Accounting Office, Washington, D.C.

30. G.A.O. 2006. "Financial restatements: Update of public company trends, market impacts, and regulatory enforcement activities." GAO-06-678, United States Government Accountability Office, Washington, D.C.

31. Gilson, S.C. 1989. "Management turnover and financial distress." Journal of Financial Economics 25: 241-262.

32. Gompers, P.A., Ishii, J.L., and A. Metrick. 2003. "Corporate governance and equity prices." Quarterly Journal of Economics 118: 107-155

33. Goyal, V.K. and C.W. Park. 2002. "Board leadership structure and CEO turnover." Journal of Corporate Finance 8: 49-66.

34. Hallock, K.F. 1997. "Reciprocally interlocking boards of directors and compensation of the CEO." Journal of Financial and Quantitative Analysis 32: 331-345.

35. Hermalin, B.E. and M.S. Weisbach. 1991. "The effects of board composition and direct incentives on firm performance." Financial Management 20: 101-112.

36. Hribar, P. and N.T. Jenkins. 2004. "The effect of accounting restatements on earnings revisions and the estimated cost of capital." Review of Accounting Studies 9: 337-356.

37. Huson, M.R., Parrino, R., and L.T. Starks. 2001. "Internal monitoring mechanisms and CEO turnover: A long-term perspective." Journal of Finance 56: 2265-2297.

38. Jensen, M.C. 1993. "The modern industrial revolution, exit, and the failure of internal control systems." Journal of Finance 48: 831-880.

39. Kang, J.K. and A. Shivdasani. 1995. "Firm performance, corporate governance, and top executive turnover in Japan." Journal of Financial Economics 38: 29-58.

40. Klein, A. 1998. "Firm performance and board committee structure." The Journal of Law and Economics 41: 275-303.

41. Livingston, J.G. 1997. "Management-borne costs of fraudulent and misleading financial reports." Ph.D. Dissertation, University of Rochester.

42. Malmendier, U. and G. Tate. 2005a. "CEO overconfidence and corporate investment." Journal of Finance 60: 2661-2700.

43. 2005b. "Does overconfidence affect corporate investment? CEO overconfidence measures revisited." European Financial Management 11: 649-659.

44. . 2008. "Who makes acquisitions? CEO overconfidence and the market's reaction." Journal of Financial Economics 89: 20-43.

45. . 2009. "Superstar CEOs." The Quarterly Journal of Economics 124: 1593-1638.

46. Martin, K.J. and J.J. McConnell. 1991. "Corporate performance, corporate takeovers, and management turnover." Journal of Finance 46: 671-687.

47. Mikkelson, W. and M. Partch. 1997. "The decline of takeovers and disciplinary management turnover." Journal of Financial Economics 44: 205-228.

48. Murphy, K.J. and J.L. Zimmerman. 1993. "Financial performance surrounding CEO turnover." Journal of Accounting and Economics 16: 273-315. 
49. Palmrose, Z-V. 1988. "An analysis of auditor litigation and audit service quality.” The Accounting Review 1: 55-73.

50. Palmrose, Z-V., Richardson, V.J., and S. Scholz. 2004. "Determinants of market reactions to restatement announcements." Journal of Accounting and Economics 37: 59-89.

51. Palmrose, Z-V. and S. Scholz. 2004. "The circumstances and legal consequences of non-GAAP reporting: Evidence from restatements." Contemporary Accounting Research 21: 139-190.

52. Shivdasani, A. and D. Yermack. 1999. "CEO involvement in the selection of new board members: an empirical analysis.” Journal of Finance 54: 1829-1853.

53. Srinivasan, S. 2005. "Consequences of financial reporting failure for outside directors: Evidence from accounting restatements and audit committee members." Journal of Accounting Research 43: 291-334.

54. Warner, J., Watts, J., and K. Wruck. 1988. "Stock prices and top management changes." Journal of Financial Economics 20: 461-492.

55. Weisbach, M.S. 1988. "Outside directors and CEO turnover." Journal of Financial Economics 20: 431460.

56. Wilson, W. 2008. "An empirical analysis of the decline in the information content of earnings following restatements." The Accounting Review 83: 519-548.

57. Wu, M. 2002. "Earnings restatements: A capital market perspective." Ph.D. Dissertation, New York University.

58. Yermack, D. 1996. "Higher market valuation of companies with a small board of directors." Journal of Financial Economics 40: 185-211. 